\title{
Hemoglobin Savannah (B6(24) $\beta$-Glycine $\rightarrow$ Valine): an Unstable Variant Causing Anemia with Inclusion Bodies
}

\author{
T. H. J. Huisman, Audrey K. Brown, G. D. Efremov, J. B. Wilson, \\ Cecelia A. Reynolds, R. Uy, and Linda L. Smith \\ From the Laboratory of Protein Chemistry and the Departments of \\ Pediatrics and Biochemistry, Medical College of Georgia, \\ Augusta, Georgia 30902
}

A в S T RACT An abnormal hemoglobin, termed $\mathrm{Hb}$ Savannah, was found in red cell hemolysate of a young Caucasian girl with severe hemolytic anemia. The presence of this unstable variant became evident when inclusion bodies appeared rapidly upon exposure of red cells to redox dyes and a large percentage of hemoglobin in hemolysate precipitated on warming to $65^{\circ} \mathrm{C}$. Treatment of the hemoglobin with $p$-hydroxymercuribenzoate ( $\mathrm{PMB}$ ) caused a rapid dissociation into monomers; starch-gel electrophoresis of PMB-treated hemoglobin showed the presence of abnormal $\beta$-chains. Data from structural studies of isolated $\beta$-chains indicated substitution of a valyl residue for the normally occurring glycyl residue at position 24, which corresponds to helical residue B6. A similar substitution but with an arginine replacing the glycyl residue has been observed in $\mathrm{Hb}$ Riverdale-Bronx. The glycine to valine substitution will change the relationship of the $B$ and the $E$ helices which results in extensive conformational changes in the $\beta$-chain. This change presumably causes an increased dissociation of the hemoglobin molecule into dimers and probably monomers, and a decreased stability of the $\alpha \beta$-dimers. The hemoglobin abnormality may be the result of a fresh mutation because the abnormality is not present in the parents nor in any of the seven siblings.

\section{INTRODUCTION}

Inclusions of precipitated hemoglobin (Heinz bodies) can be observed in the red blood cells of patients with several forms of hemolytic anemia. Recently it has become evident that the primary defect in some of these disorders is the hemoglobin molecule itself because of the presence of unstable variants. The use of routine electrophoretic or chromatographic procedures for the

\footnotetext{
* Deceased, 9 March 1970.

Received for publication 11 September 1970.
}

purpose of identification and isolation is often only partially successful. Apparently substitution of amino acid residues in critical positions of either $\alpha$ - or $\beta$-chains may decrease the stability of these proteins to an extent that such changes in physical properties can interfere with their identification. Moreover, in several of these unstable variants the abnormality concerns an amino acid substitution involving no change in charge (references 1-4 present comprehensive reviews of the variations in the structures of many unstable hemoglobins).

The present report describes a hemoglobinopathy which was discovered in a Caucasian girl with congenital nonspherocytic hemolytic anemia; the abnormality was not found in the parents or in any of the seven brothers and sisters of the patient. Hematological studies of this child and the chemical characterization of the abnormal hemoglobin are reported. The initial studies were hampered greatly by the inability to isolate the abnormal hemoglobin in a sufficiently pure state and in an amount that would allow the identification of the structural defect. The use of methods applied by Rosemeyer and Huehns in their studies on the dissociation mechanism of hemoglobin (5) and by Rieder, Oski, and Clegg in their investigations of the $\mathrm{Hb}$ Philly abnormality (6) greatly facilitated our chemical analyses.

\section{METHODS}

Hematologic studies. Routine hematologic examinations were made by standard methods (7). Hemolysates were prepared by mixing 1 volume of washed, packed, red cells, 1 volume of distilled water, and 0.2 volume of carbon tetrachloride for $10 \mathrm{~min}$. Stroma was removed by centrifugation at $8000 \mathrm{~g}$ for $20 \mathrm{~min}$ at $4^{\circ} \mathrm{C}$. Time lapse between blood collection and the first (usually electrophoretic) analysis was 3-6 hr.

Hemoglobin studies. Electrophoresis of samples containing about $100 \mathrm{mg} / \mathrm{ml}$ of hemoglobin was done at $6 \mathrm{v} / \mathrm{cm}$ and at $4^{\circ} \mathrm{C}$ overnight with starch gel in $\mathrm{pH} 9.0$ Tris-EDTAboric acid buffer $(8)$. The gels were stained with 0 -dianisi- 
dine and with Buffalo black (9). Chromatography on columns of DEAE-Sephadex was used on occasion to quantitate hemoglobin fractions $(10,11)$. Chromatography of hemoglobin solutions on columns $(2.5 \times 150 \mathrm{~cm})$ of Sephadex G-75 in a buffer containing $0.12 \mathrm{M}$ glycine- $\mathrm{NaOH}$ and $0.12 \mathrm{M}$ sodium chloride, $\mathrm{pH} 10.1$, followed previously described methods $(12,13)$. The technique of Betke, Marti, and Schlicht was used to quantitate the alkali-resistant hemoglobin (14). The heat stability of the hemoglobin in red cell hemolysates was tested by incubation of hemoglobin (final concentration $1.5 \mathrm{mg} / \mathrm{ml}$ ) at $65^{\circ} \mathrm{C}$ in $0.2 \mathrm{M}$ sodium phosphate buffer, $\mathrm{pH}$ 6.5. The percentage heat-precipitated hemoglobin was calculated from the amount originally present and that remaining in solution; the method is a slight modification of the procedure described by Grimes, Meisler, and Dacie (15). The presence of an abnormal hemoglobin was also studied by starch-gel electrophoresis of the PMB ( $p$-hydroxymercuribenzoate, sodium salt, Sigma Chemical Co., St. Louis, Mo.) derivatives of the hemoglobins from the propositus and her relatives. These derivatives were prepared by reacting the hemoglobin for 3 hr with a fourfold or with a twelvefold molar excess of

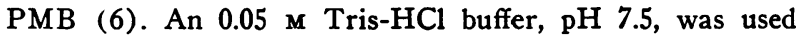
in these experiments in which the final hemoglobin concentration varied between 30 and $35 \mathrm{mg} / \mathrm{ml}$.

Isolation of the abnormal $\beta$-chain. The technique was a modification of methods used by Rosemeyer and Huehns (5), and was suggested to us by Dr. E. R. Huehns. $10 \mathrm{ml}$ of a freshly prepared hemolysate $(100 \mathrm{mg} \mathrm{COHb} / \mathrm{ml})$ was mixed with $50 \mathrm{ml} 0.1 \mathrm{M}$ sodium phosphate buffer, $\mathrm{pH} 6.0$, $10 \mathrm{ml} 2 \mathrm{M} \mathrm{NaCl}$ solution, $20 \mathrm{ml}$ distilled water, and $10 \mathrm{ml}$ PCMB solution ( $p$-chloromercuribenzoate, sodium salt, $\mathrm{Nu}$ tritional Biochemicals Corp., Cleveland. Ohio; $10 \mathrm{mg} / \mathrm{ml}$, $\mathrm{pH}$ about 10 , prepared by dissolving the $\mathrm{PCMB}$ in a minimal amount of $1 \mathrm{~N} \mathrm{NaOH}$ and adjusting the $\mathrm{pH}$ with $1 \mathrm{~N}$ acetic acid until slightly turbid). The mixture was stirred for $90 \mathrm{~min}$ at $4^{\circ} \mathrm{C}$. The precipitate was washed repeatedly with a mixture of $100 \mathrm{ml} 0.1 \mathrm{M}$ sodium phosphate buffer, $\mathrm{pH} 6.0,20 \mathrm{ml} 2 \mathrm{M} \mathrm{NaCl}$, and $60 \mathrm{ml}$ water, and finally dissolved in a minimal volume of $1 \%$ solution of trimethylamine (TMA, Eastman Kodak Co., Rochester, N. Y.). The solution was passed through a $2 \times 30 \mathrm{~cm}$ column of Sephadex G-25 (in $0.2 \%$ TMA) whereafter the hemoglobincontaining effluent was exposed to excess of cysteine (1 $\mathrm{mg} / \mathrm{ml}$ ). The hemoglobin was dialyzed for $24 \mathrm{hr}$ at $4^{\circ} \mathrm{C}$ against several changes of an $0.2 \%$ TMA solution. Heme was removed from the hemoglobin by the acid-acetone procedure of Anson and Mirsky (16).

Structural analyses. Approximately $230 \mathrm{mg}$ of isolated $\beta$-chain was hydrolyzed with trypsin (Worthington Biochemical Corp., crystallized three times, salt-free) at room temperature for $2 \mathrm{hr}$ at $\mathrm{pH} 8.9$ in a $\mathrm{pH}$-stat. Trypsin equal to $0.5 \%$ of the weight of the $\beta$-chain was added at zero time and again $30 \mathrm{~min}$ later. After completion of the hydrolysis, the $\mathrm{pH}$ was lowered to 6.5 with $1.0 \mathrm{~N} \mathrm{HCl}$ and the insoluble core removed by centrifugation. The $\mathrm{pH}$ of the supernatant was lowered further to 2.5 whereafter the soluble peptides were taken to dryness by flash evaporation at $37^{\circ} \mathrm{C}$.

The peptides were separated by chromatography on a $1 \times 100 \mathrm{~cm}$ column of Dowex $50-\mathrm{X} 2$ with volatile pyridineacetic acid developers $(17,18)$. Each Dowex 50 zone was rechromatographed on a column of Dowex 1-X2 (19). The abnormal $\beta \mathrm{T}-3$ peptide was degraded by acetic acid hydrolysis and by digestion with thermolysin (20-23). Approximately $2 \mu$ moles of peptides were hydrolyzed with $0.25 \mathrm{~N}$ acetic acid for $48 \mathrm{hr}$ in vacuo and in a boiling water bath. The resulting peptide fragments were separated on a $0.6 \times 60 \mathrm{~cm}$ column of Dowex $50-\mathrm{X} 2$ according to the method described by Schroeder (24). The thermolysin digestion followed the direction of Matsubara, Sasaki, Singer, and Jukes $(20)$; about $1.6 \mu$ moles of $\beta \mathrm{T}-3$ were incubated with $2 \mathrm{mg}$ thermolysin (three times crystallized, A grade, Calbiochem, Los Angeles, Calif.) for $8 \mathrm{hr}$ at $\mathrm{pH} 8.8$ and at $37^{\circ} \mathrm{C}$. The hydrolysate was dried by flash evaporation and chromatographed on a column of Dowex 1-X2 (19). Sequential data on some fragments of the $\beta \mathrm{T}-3$ peptide resulted from analyses made with the modified Edman phenylthiohydantoin procedure (25).

The insoluble core was oxidized with performic acid according to a slight modification of the procedure described by Hirs (26). Attempts were made to purify this oxidized core $(25 \mathrm{mg})$ by passage through a $1.0 \times 155 \mathrm{~cm}$ column of Sephadex G-50 in 0.5\% formic acid followed by Dowex 1-X2 chromatography (19).

Amino acid analyses were made with a Spinco model $120 \mathrm{~B}$ amino acid analyzer equipped with a long path flow cell (27). Samples were hydrolyzed at $110^{\circ} \mathrm{C}$ under reduced pressure with $6 \mathrm{~N} \mathrm{HCl}$. The time of hydrolysis was $24 \mathrm{hr}$ and occasionally $72 \mathrm{hr}$. Tryptophan was identified by spot test on paper (28).

Sedimentation analyses of selected hemoglobin components were made with a Spinco model $\mathrm{E}$ analytical ultracentrifuge at $60,000 \mathrm{rpm}$ and at $25^{\circ} \mathrm{C}$; the procedure was identical with that used in a previous study (8).

\section{RESULTS}

Case report. The propositus (W. S. W.), born in 1958 , was first seen by us at the age of 16 months because of severe unremitting anemia. This Caucasian female had been the product of an uncomplicated 9 month pregnancy. She is one of eight children and neither parents nor siblings have had any known anemia. The physical findings at the age of 16 months showed pulse 120 , respiration 20 , and temperature $37.6^{\circ} \mathrm{C}$. She was well developed and well nourished but quite pale. There was a grade III systolic murmur over the precordium and P2 was slightly accentuated. The liver was palpable two finger breadths below the right costal margin and the spleen $3 \frac{1}{2}$ finger breadths below the left costal margin. Laboratory data included: total $\mathrm{Hb} 5.5 \mathrm{~g} / 100$ $\mathrm{ml}$; PCV 19\%; WBC $13,350 / \mathrm{mm}^{3}$ with 41 segs, 50 lymps, 1 mono, and 8 eos; platelet count was $250,000 /$ $\mathrm{mm}^{3}$. Reticulocyte count was $50 \%$ and marked "basophilic stippling" was noted. Direct Coombs was negative. RBC osmotic fragility was normal but mechanical fragility was increased. Total bilirubin varied between 1.2 and $2.4 \mathrm{mg} / 100 \mathrm{ml}$ and direct bilirubin was $<0.5 \mathrm{mg} /$ $100 \mathrm{ml}$. Starch-gel electrophoresis of red cell hemolysate at $\mathrm{pH} 8.1$ indicated the possible presence of an abnormal component which had a mobility slightly slower than that of $\mathrm{HbA}$. The level of alkali-resistant hemoglobin was $9 \%$.

The patient was readmitted at the age of 19 months for a splenectomy. At time of admission the total hemoglobin level was $3.7 \mathrm{~g} / 100 \mathrm{ml}$, which after transfusion 


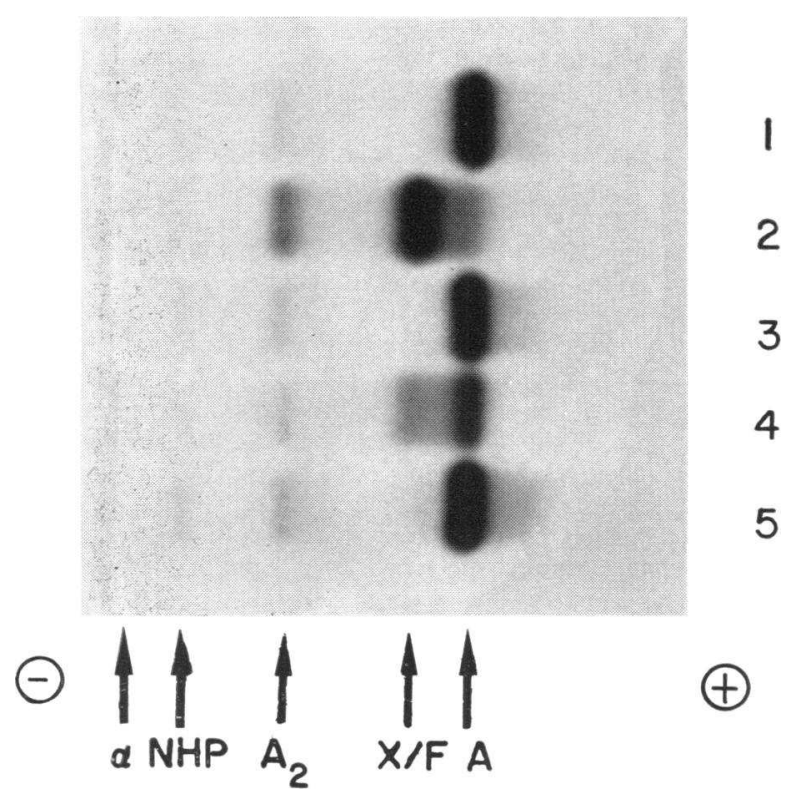

FIGURE 1 Starch-gel electrophoretic pattern of the hemoglobin Savannah abnormality. Tris-EDTA-borate buffer, $\mathrm{pH}$ 9.0 ; anode on the right, stained with Amido black 10B. (1) Normal control; (2) cord blood from AC heterozygote; (3) mother; (4) propositus; (5) father. NHP designates nonhemoglobin protein fraction.

rose to $8.2 \mathrm{~g} / 100 \mathrm{ml}$. The reticulocyte count was still some $40 \%$. At surgery the spleen was found to weigh $175 \mathrm{~g}$ and there were two accessory spleens. The surgical pathology description of the spleen indicated congestion and erythrostasis.

Although the child was followed episodically in the outpatient department, she was lost to follow-up for several years. At the age of $8 \mathrm{yr}$ she was readmitted. Laboratory data included: total $\mathrm{Hb} 6.3 \mathrm{~g} / 100 \mathrm{ml}$; PCV $23 \%$; RBC $2.07 \times 10^{8} / \mathrm{mm}^{3} ; \mathrm{MCV} 111 \mu^{3} ; \mathrm{MCH} 30$ $\mu \mu \mathrm{g}$; $\mathrm{MCHC} 27 \%$; reticulocytes $18.9 \%$; for the first

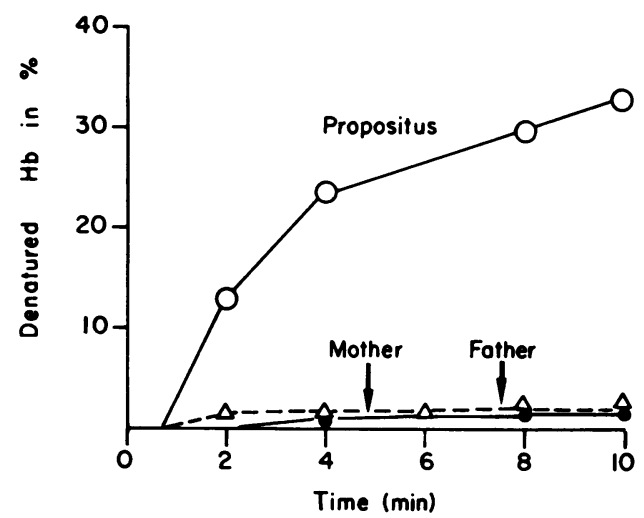

Figure 2 The instability of the hemoglobin of the propositus on warming to $65^{\circ} \mathrm{C}$. See text for details. time the inclusions in about $50 \%$ of the red cells were defined as Heinz bodies. (A comparison of these smears with those prepared presplenectomy was unfortunately not possible.) There were also 66 nucleated red cells per 100 white cells. Bilirubin was $2.4 \mathrm{mg} / 100 \mathrm{ml}$. The red cell pyruvate kinase activity was markedly increased to $27 \mathrm{U}$ and that of G6PD was slightly increased to $17.9 \mathrm{U}$.

In general the patient continues to do reasonably well with a hemoglobin that stabilizes between 5.5 and 7.0 $\mathrm{g} / 100 \mathrm{ml}$ and with a reticulocyte count of about $20-30 \%$.

The cardio-thoracic ratio is slightly greater than normal. The level of alkali-resistant hemoglobin in blood samples which were collected when the patient was $8 \mathrm{yr}$ and older never exceeded $3 \%$.

Starch-gel electrophoresis of hemolysate from the propositus at $\mathrm{pH} 9.0$ and $4{ }^{\circ} \mathrm{C}$ demonstrated an abnormal hemoglobin with a mobility about similar to that of $\mathrm{Hb} \mathrm{F}$ (Fig. 1). A minute amount of possibly free $\alpha$-chains was also observed. No abnormal hemoglobin was detected in hemolysate from the parents (samples 3 and 5 of Fig 1) or from that of her six brothers and one sister. Hematologic values made on blood samples of the parents and the siblings have been normal and have shown no evidence of increased hemolysis. The levels of $\mathrm{Hb} \mathrm{A}_{2}$ in the father and the mother were determined by DEAESephadex chromatography, and were 2.6 and $2.3 \%$, respectively.

Fig. 2 illustrates the heat lability of the hemoglobin of hemolysate from the propositus. Approximately $30 \%$ of the hemoglobin precipitated after 8-10 min of incubation at $65^{\circ} \mathrm{C}$, whereas no significant precipitation was observed in hemolysates from the parents.
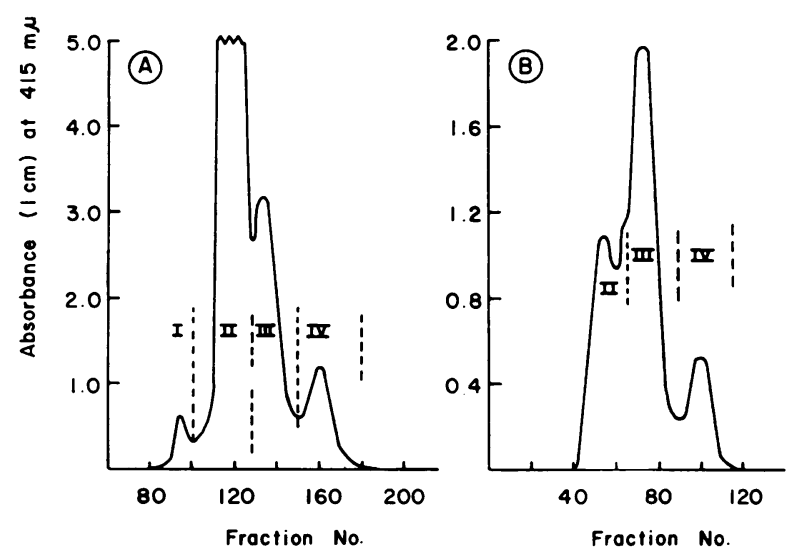

FigURE 3 Chromatography of hemolysate from propositus (A) and of the isolated fraction III (B) on columns of Sephadex G-75 at $\mathrm{pH}$ 10.1. (A) Two columns $(2.5 \times 150$ $\mathrm{cm}$ each) in series; $300 \mathrm{mg}$ of hemoglobin from hemolysate in $7 \mathrm{ml}$ was applied. Fraction volume $3.8 \mathrm{ml}$; flowrate 15 $\mathrm{ml} / \mathrm{hr}$. (B) One column $2.5 \times 150 \mathrm{~cm} ; 50 \mathrm{mg}$ of fraction III in $5 \mathrm{ml}$ was applied. Fraction volume $3.3 \mathrm{ml}$; flow rate $15 \mathrm{ml} / \mathrm{hr}$. 
TABLE I

Amino Acid Composition of Some Isolated Hemoglobin Fractions*

\begin{tabular}{lccccrr}
\hline \multicolumn{1}{c}{ Amino acids } & $\begin{array}{c}\text { Fraction } \\
\text { III }\end{array}$ & $\begin{array}{c}\alpha \beta / 2 \\
\text { theo- } \\
\text { retical }\end{array}$ & $\begin{array}{c}\text { Fraction } \\
\text { IV } \neq\end{array}$ & $\begin{array}{c}\alpha \text {-Chain } \\
\text { theo- } \\
\text { retical }\end{array}$ & $\begin{array}{c}\text { Abnormal } \\
\text { precipi- } \\
\text { tate\& }\end{array}$ & $\begin{array}{c}\beta \text {-Chain } \\
\text { theo- } \\
\text { retical }\end{array}$ \\
\hline Lysine & 11.0 & 11 & 11.0 & 11 & 11.0 & 11 \\
Histidine & 8.8 & 9.5 & 10.3 & 10 & 7.9 & 9 \\
Arginine & 2.9 & 3 & 3.3 & 3 & 4.5 & 3 \\
Aspartic acid & 13.0 & 12.5 & 12.4 & 12 & 13.9 & 13 \\
Threonine & 7.5 & 8 & 8.2 & 9 & 7.3 & 7 \\
Serine & 7.8 & 8 & 9.7 & 11 & 6.3 & 5 \\
Glutamic acid & 8.4 & 8 & 5.6 & 5 & 13.4 & 11 \\
Proline & 6.7 & 7 & 6.6 & 7 & 7.0 & 7 \\
Glycine & 9.8 & 10 & 7.0 & 7 & 11.4 & 13 \\
Alanine & 17.6 & 18 & 19.8 & 21 & 15.1 & 15 \\
Cysteine & - & 1.5 & - & 1 & 1.7 & 2 \\
Valine & 14.0 & 15.5 & 12.5 & 13 & 15.2 & 18 \\
Methionine & 1.1 & 1.5 & 1.7 & 2 & 2.0 & 1 \\
Isoleucine & 0.1 & 0 & 0 & 0 & 1.9 & 0 \\
Leucine & 18.0 & 18 & 18.1 & 18 & 18.1 & 18 \\
Tyrosine & 2.6 & 3 & 2.4 & 3 & 3.2 & 3 \\
Phenylalanine & 7.3 & 7.5 & 6.8 & 7 & 7.7 & 8 \\
\hline
\end{tabular}

* Duplicate analyses of $24 \mathrm{hr}$ acid hydrolysates. Calculations are relative to lysine. $\ddagger$ From chromatogram of Fig. $3 \mathrm{~B}$.

$\S$ Isolated by PCMB treatment, see also Fig. 5.

Chromatographic investigations. DEAE-Sephadex as well as CM-cellulose chromatography failed to resolve the abnormal hemoglobin from normal $\mathrm{Hb} \mathrm{A}$. A distinct fetal hemoglobin zone was not present in these chromatograms. The level of $\mathrm{Hb} \mathrm{A}_{2}$ in the patient was $2.1 \%$. The DEAE-Sephadex chromatogram showed an additional minor fraction (about $0.4 \%$ ), which was eluted in front of the $\mathrm{Hb} \mathrm{A}_{2}$ component; this fraction had an electrophoretic mobility similar to that of free $\alpha$-chains.

Chromatography of hemolysate from the patient on Sephadex G-75 columns resulted in the (incomplete) resolution of several components. A representative chromatogram is given in Fig. $3 \mathrm{~A}$; approximately 300 $\mathrm{mg}$ of hemoglobin, dialyzed for $24 \mathrm{hr}$ against the $\mathrm{pH}$ 10.1 glycine- $\mathrm{NaOH}-\mathrm{NaCl}$ buffer and dissolved in a final volume of $7 \mathrm{ml}$, was chromatographed on two columns $(2.5 \times 150 \mathrm{~cm})$ placed in series. Of the four components fraction I seems to be a nonhemoglobin component complexed with bilirubin. Fractions II, III, and IV were concentrated by ultrafiltration in vacuo and at $4^{\circ} \mathrm{C}$, and analyzed by starch-gel electrophoresis. Fraction II consisted of $\mathrm{Hb} \mathrm{A}$ and $\mathrm{Hb} \mathrm{A}_{2}$ only, and fraction III primarily of the abnormal hemoglobin component, whereas fraction IV could not be definitely identified. The total amount of fractions III and IV varied between 13 and $17 \%$ in several chromatograms. Fractions III from these chromatograms were combined and rechromatographed on a $2.5 \times 150 \mathrm{~cm}$ column of Sephadex G-75 at pH 10.1 . This chromatogram (Fig. $3 \mathrm{~B}$ ) shows an incomplete resolution of fraction III and two additional components (fractions II and IV). The amino acid compositions of components III and IV from the chromatogram of Fig. $3 \mathrm{~B}$ are presented in Table I. The results of these analyses are consistent with the assumption that fraction IV consists primarily of $\alpha$-chains and fraction III of an equal mixture of $\alpha$ - and $\beta$-chains.

TABLE II

$\boldsymbol{s}_{\mathbf{2 0}, \boldsymbol{w}}$ Values for Hemoglobin Fractions Isolated from Sephadex G-75 Chromatograms*

\begin{tabular}{rccccc}
\hline pH $\ddagger$ & $\begin{array}{c}\text { Compo- } \\
\text { nent II } \\
\text { Fig. 3 A }\end{array}$ & $\begin{array}{c}\text { Compo- } \\
\text { nent III } \\
\text { Fig. 3 A }\end{array}$ & $\begin{array}{c}\text { Compo- } \\
\text { nent III } \\
\text { Fig. 3 B }\end{array}$ & $\begin{array}{c}\text { Compo- } \\
\text { nent IV } \\
\text { Fig. 3 A }\end{array}$ & $\begin{array}{c}\text { Compo- } \\
\text { nent IV } \\
\text { Fig. 3 B }\end{array}$ \\
\hline 7.4 & 3.94 & 3.47 & & & \\
7.4 & 3.92 & & & & 3.35 \\
8.9 & 4.12 & & 3.22 & & \\
9.4 & 4.04 & & 3.12 & & \\
10.1 & 3.91 & 2.67 & & & \\
10.1 & 3.99 & & & 3.35 & \\
10.1 & 3.89 & & & & 2.95 \\
10.1 & 3.99 & & 2.67 & & \\
\hline
\end{tabular}

* A final hemoglobin concentration of $0.45-0.50 \mathrm{~g} / 100 \mathrm{ml}$ was used in all experiments. The following buffer systems were used in concentrations varying between 0.07 and $0.18 \mathrm{~mole} /$ liter; $\mathrm{KH}_{2} \mathrm{PO}_{4}-\mathrm{NaOH}(\mathrm{pH} 7.4)$; and $\mathrm{NaCl}$-glycine- $\mathrm{NaOH}$ (pH 8.9-10.1).

$\ddagger \mathrm{pH}$ measurements at $25^{\circ} \mathrm{C}$. 


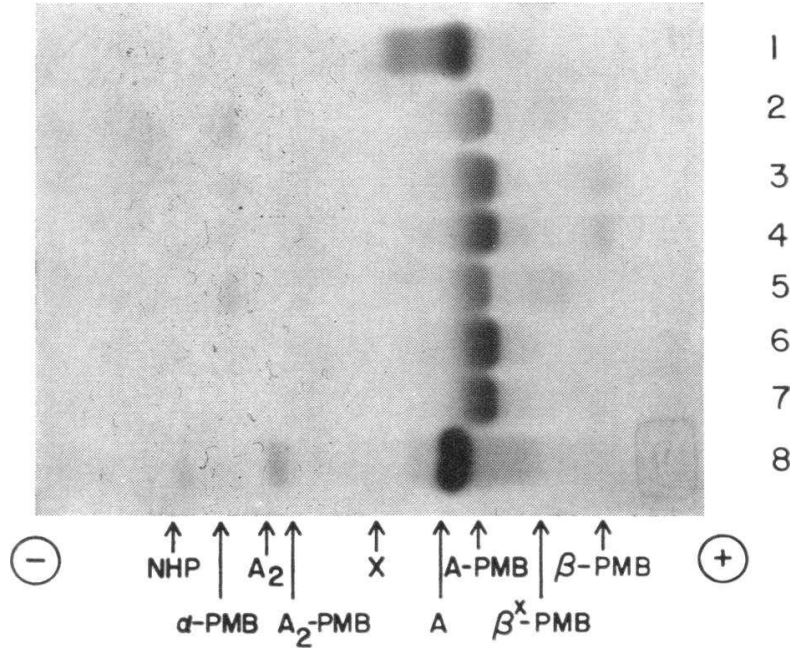

FIGURE 4 Starch-gel electrophoresis at $\mathrm{pH} 9.0$ and $4^{\circ} \mathrm{C}$ of hemolysates treated with PMB. Samples 1 and 8 untreated hemoglobin from propositus and her father, respectively. Samples 2 (propositus), 3 (mother), and 4 (father) were treated with $12 \mathrm{mmoles} \mathrm{PMB} / \mathrm{mmole}$ of hemoglobin. Samples 5 (propositus), 6 (mother), and 7 (father) were treated with 4 mmoles $\mathrm{PMB} / \mathrm{mmole}$ of hemoglobin. Gel is stained with Amino black 10B. NHP denotes nonhemoglobin protein fraction, $\mathrm{X}$ the abnormal hemoglobin. For further details see text.

Table II lists sedimentation velocity data of components II, III, and IV as a function of the $\mathrm{pH}$. Component III appears to be dissociated into dimers to a greater extent than component II ; the dissociation of component III into half molecules is complete at $\mathrm{pH} 10.1$. Fraction IV, which because of its position in the Sephadex G-75 chromatogram and of the data from the amino acid analysis is considered to be primarily free $\alpha$-chains, showed surprisingly high $s$ 20,w values both at $\mathrm{pH} 7.4$ and at $\mathrm{pH}$ 10.1. Apparently concentrating this fraction IV from about $10 \mathrm{mg} / 100 \mathrm{ml}$ (the mean concentration of this fraction in the column effluent) to about $500 \mathrm{mg} / 100$ $\mathrm{ml}$ (the average concentration used in the ultracentrifugation experiments) resulted in a considerable aggregation of these subunits, which is not greatly affected by a change in the $\mathrm{pH}$.

Electrophoretic mobility of an abnormal hemoglobin subunit. Red cell hemolysates from the propositus and her parents were exposed for $3 \mathrm{hr}$ to 4 mmoles and 12 mmoles of PMB per mmole of hemoglobin in $0.05 \mathrm{M}$ Tris- $\mathrm{HCl}$ buffer, $\mathrm{pH}$ 7.5. Electrophoretic examination showed an incomplete dissociation of the hemoglobins from the propositus and her parents into the monomeric $\alpha$-PMB and $\beta$-PMB chains in mixtures with the highest PMB to hemoglobin ratio (Fig. 4). A similar dissociation after exposure to a lower relative PMB concentration was seen in the hemoglobin from the propositus and almost not in that from normal controls. The mobility of the fast moving PMB chain in the 4 mmoles PMB to 1 mmole of hemoglobin mixture from the propositus (termed $\beta^{x}-P M B$ chain) was distinctly slower than that of the $\beta$-PMB chain of normal hemoglobin A. This difference can also be observed in the 12 mmoles PMB to 1 mmole of hemoglobin mixture because of the simultaneous formation of the $\boldsymbol{\beta}^{\mathbf{x}}-\mathrm{PMB}$ and $\boldsymbol{\beta}^{\boldsymbol{A}}-\mathrm{PMB}$ subunits.

Structural studies of the abnormal $\beta^{x}$-Chain. The $\beta^{\mathbf{X}}$-PMB chain was prepared from red cell hemolysate of the propositus by treatment with PCMB as described in the methods section. Electrophoretic examination of the precipitate (dissolved in 1\% TMA) and of the supernatant showed that the $\beta^{\mathbf{X}}$-PMB chain was only slightly contaminated with the $\alpha$-PMB chain, whereas $\mathrm{Hb}$ $\mathrm{A}-\mathrm{PMB}, \mathrm{Hb}$ Ar-PMB, and $\alpha-\mathrm{PMB}$ chain were the hemoglobin components present in the supernatant (Fig. 5). Apparently the conditions of this experiment do not cause dissociation of $\mathrm{Hb}$ A-PMB and $\mathrm{Hb}$ $\mathrm{A}_{2}-\mathrm{PMB}$. The amino acid composition of the globin prepared from the $\beta^{\mathbb{x}}$-chain suggested a notable contamination of this hemoglobin chain with other (probably nonhemoglobin) protein (Table I). Attempts to further purify the $\beta^{\mathbf{x}}$-chain by CM-cellulose chromatography (29) were not successful because of the insolubility of this material in $8 \mathrm{~m}$ urea with 2-mercaptoethanol. A similar complication also prevented a successful reaction of the $\beta^{\mathbf{x}}$-chain with ethylenimine to form the S-aminoethyl derivative (30).

The soluble peptides in a tryptic hydrolysate of $\beta^{\mathbf{x}}$-chain were separated by Dowex $50-\mathrm{X} 2$ chromatography whereas the major Dowex 50 zones were rechromatographed on columns of Dowex 1-X2 to obtain peptides with an acceptable purity. The amino acid compositions of these peptides are given in Table III. The tryptic peptides T-1, T-2, T-3, T-4, T-5, T-6, T-7, T-8, $T-8,9, T-9, T-13, T-14$, and $T-15$ could readily be identified and no additional peptides were observed. All peptides had amino acid compositions identical with those of the corresponding peptides from normal $\beta^{\boldsymbol{A}}$-chain except pep-

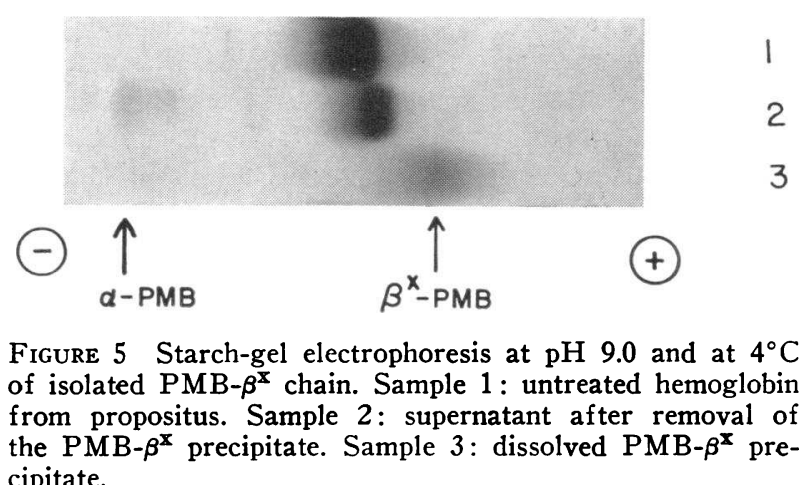
cipitate. 
TABLE III

Amino Acid Composition of the Soluble Tryptic Peptides from a $2 \mathrm{hr}$ Digest of the $\beta$-Chain of Hb-Savannah*

\begin{tabular}{|c|c|c|c|c|c|c|c|c|c|c|c|c|c|}
\hline Amino acid & $T-1$ & $\mathrm{~T}-2$ & $T-3 \ddagger$ & $T-4$ & $T-5$ & $T-6$ & T-7 & $T-8$ & T-9 & $T-8,9$ & $T-13$ & $T-14$ & T-15 \\
\hline Lysine & 1.00 & 1.00 & & & 1.00 & 1.00 & 1.00 & 1.00 & 1.00 & 2.00 & 1.00 & 1.00 & \\
\hline Histidine & 0.94 & & & & & & 0.81 & & 0.92 & 0.96 & & 0.94 & 1.00 \\
\hline Arginine & & & $1.00(1.00)$ & 1.00 & & & 0.15 & & & & & & \\
\hline Aspartic acid & 0.17 & 0.14 & $2.14(2.02)$ & & 3.11 & & & & 2.92 & 2.98 & 0.25 & 1.00 & \\
\hline Threonine & 0.94 & 0.90 & & & 1.01 & & 0.11 & & & & 0.95 & & \\
\hline Serine & & 0.92 & & 0.92 & 1.98 & & & & 1.17 & 1.04 & 0.28 & & \\
\hline Glutamic acid & 2.02 & 0.19 & $2.03(2.01)$ & 1.02 & 1.18 & & 0.11 & & 0.23 & & 3.09 & & \\
\hline Proline & 0.94 & & & 0.80 & 1.77 & & 0.10 & & & & 2.05 & & \\
\hline Glycine & 0.14 & 1.04 & $1.91(2.03)$ & & 2.01 & & 0.96 & & 1.92 & 2.05 & 0.21 & 1.03 & \\
\hline Alanine & 0.14 & 1.89 & $0.96(1.07)$ & & 1.03 & & 0.80 & & 2.17 & 2.07 & 2.07 & 3.97 & \\
\hline Valine & 0.96 & 1.04 & $3.338(3.89)$ & $1.54 \S$ & 1.01 & 0.83 & 0.23 & & 1.00 & 0.95 & 1.09 & $2.25 \S$ & \\
\hline Methionine & & & & & 0.65 & & & & & & & & \\
\hline Leucine & 1.10 & 1.00 & $0.95(1.07)$ & 1.95 & 1.10 & & 0.19 & & 3.83 & 4.22 & & 1.03 & \\
\hline Tyrosine & & & & 0.93 & & & & & & & 0.86 & & 0.86 \\
\hline Phenylalanine & & 0.10 & & & 2.72 & & & & 0.91 & 0.97 & 0.87 & & \\
\hline Tryptophan\| & & + & & + & & & & & & & & & \\
\hline Total & 8 & 9 & 13 & 10 & 19 & 2 & 4 & 1 & 16 & 17 & 12 & 12 & 2 \\
\hline Yield $(\%)$ ฯ & 61 & 24 & 84 & 20 & 45 & 51 & 60 & 15 & 48 & 25 & 33 & 45 & 60 \\
\hline
\end{tabular}

* Data are presented as residues relative to lysine, arginine, or histidine. Amino acids present to less than 0.1 residues are omitted. No correction factors have been applied to amino acids which are partially destroyed during acid hydrolysis. Samples were hydrolyzed at $110^{\circ} \mathrm{C}$ under reduced pressure with $6 \mathrm{~N} \mathrm{HCl}$ for $24 \mathrm{hr}$.

$\ddagger$ Data between parentheses refer to analysis of a $72 \mathrm{hr}$ hydrolysate.

\&ow recovery due to the presence of a Val-Val bond.

|| Determined by color reaction on paper (28).

I Calculated on the basis of the recovery after Dowex 50 and subsequent Dowex 1 chromatography, assuming a $100 \%$ hydrolysis at the appropriate cleavage points during tryptic hydrolysis.

tide T-3. The composition of this peptide showed an apparent replacement of one of the three normally occurring glycyl residues by a valyl residue. The recovery of this fourth valyl residue was low in a $24 \mathrm{hr}$ acid hydrolysate, but improved greatly when the hydrolysis time was extended to $72 \mathrm{hr}$. This observation indicates the presence of a Val-Val peptide bond in this peptide which is known to resist acid hydrolysis. It may then be possible that a substitution of valine for glycine occurred at the seventh residue of the $\mathrm{T}-3$ peptide as suggested in the sequence of Fig. 6.

The amino acid composition of the fragments which resulted from a mild acetic acid hydrolysis of the abnormal T-3 peptide is presented in Table IV. Zones 1 and 3 from the Dowex 50-X2 chromatogram were identified as (rather impure) free aspartic acid and the tripeptide Asx, $\mathrm{Val}_{2}$, respectively. A nonapeptide was present in zone 2 , and its amino acid composition was consistent with the nine carboxy-terminal amino acid residues of the $T-3$ peptide except for a glycine $\rightarrow$ valine substitution. The recovery of 1.6 and of 2.0 residues of valine in the $24 \mathrm{hr}$ and the $72 \mathrm{hr}$ hydrolysates, respecspectively, again suggests a Val-Val sequence in this peptide. Stepwise degradation of this peptide with the
PTH procedure was not successful probably because of cyclization of the amino terminal glutamyl residue during acetic acid hydrolysis.

Four distinct zones were present in the Dowex-1 chromatogram of the thermolysin digest of the $\beta \mathrm{T}-3$ peptide (Fig. 7). The amino acid composition of these peptide fragments, given in Table IV, readily identified zone 1 as the tripeptide originating from the carboxyterminus and zone 2 as the dipeptide originating from the amino-terminus. The amino acid composition of 24 $\mathrm{hr}$ hydrolysate of the material from zone 3 suggested a pentapeptide Glu, Gly, Ala, Vals (segment B-3,4 of Fig. 6). However, the recovery of valine in $72 \mathrm{hr}$ hydrolysate increased to 1.73 and 1.61 residues instead of 2 residues in two separate experiments which indicates that a mixture of the Glu, Gly, Ala, Val pentapeptide and the Glu, Gly, Ala, Val tetrapeptide (segment B-4 of Fig. 6) is present in a ratio of about $2: 1$. PTH degradation of the material from zone 3 gave a valyl as aminoterminal residue, whereas a mixture of a glycyl residue and a valyl residue was observed after the next degradation. These results suggest the presence of two peptides: one with a Val, Gly amino-terminal sequence (segment B-4) and a second with a Val-Val amino-terminal se- 


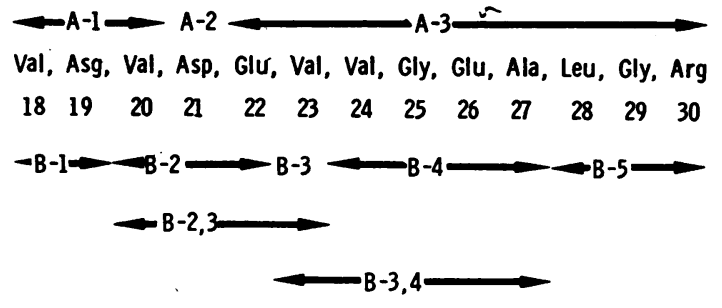

FIGURE 6 Proposed sequence of the $\beta \mathrm{T}-3$ peptide of $\mathrm{Hb}-$ Savannah. The numbers indicate positions of amino acid residues in the $\beta$-chain. The $A$ fragments resulted from hydrolysis with dilute acetic acid, and the B fragments from hydrolysis with thermolysin.

quence (segment B-3,4). Data from amino acid analysis of zone $4+5$ showed the likely presence of two peptides (segments B-2 and B-2,3 of Fig. 6); the tetrapeptide Val, Asp, Glu, Val is eluated slightly faster than the Val, Asp, Glu peptide.

The insoluble core (peptides T-10, T-11, and T-12, together 38 amino acid residues) was oxidized with performic acid and the resulting material purified by passage through columns of Sephadex G-75, and by rechromatography on Dowex 1-X2. Data from amino acid analysis of the "purified" core indicated a considerable contamination which made it impossible to determine the exact amino acid composition of this portion of the $\beta$-chain.

\section{DISCUSSION}

The hemoglobin abnormality, for which the name $\mathrm{Hb}$ Savannah is proposed, is one of the several variants which are usually associated with accelerated in vivo destruction of red blood cells, with in vitro production of inclusion bodies in erythrocytes exposed to redox dyes, and with precipitation of hemoglobin upon heating to temperatures of $50^{\circ}-70^{\circ} \mathrm{C}(1-4)$. The heterozygous state for this newly discovered unstable variant causes a rather severe hemolytic anemia which required medical attention of the patient at the age of about $1 \mathrm{yr}$ and which did not significantly improve after splenectomy. It may be that the $\mathrm{Hb}$ Savannah abnormality, like $\mathrm{Hb}$ Sabine (31), arose as a fresh mutation because the abnormality is absent in the parents and the seven siblings. There was no reason to suspect nonpaternity but no attempt was made to exclude this possibility by blood group analysis.

In $\mathrm{Hb}$ Savannah there is a substitution of a glycyl residue by a valyl residue in position 24 of the $\beta$-chain. The conclusion that a Val-Val-Gly sequence exists in

TABLE IV

Amino Acid Composition of Fragments Isolated from an Acetic Acid Hydrolysate and from a Thermolysin Hydrolysate of the $\beta T-3$ Peptide of Hb-Savannah

\begin{tabular}{|c|c|c|c|c|c|c|c|c|c|}
\hline \multirow[b]{2}{*}{ Amino acid } & \multicolumn{3}{|c|}{ Acetic acid hydrolysate* } & \multicolumn{6}{|c|}{ Thermolysin hydrolysate* } \\
\hline & Zone 1 & Zone 2 & Zone 3 & Zone 1 & Zone 2 & Zone 3 & Zone $4+5$ & Zone 4 & Zone 5 \\
\hline Lysine & & 0.10 & & & & & & & \\
\hline Arginine & & $1.00(1.00)$ & & 1.00 & & & & & \\
\hline Aspartic acid & 1.00 & $0.19(0.13)$ & 1.00 & & 1.01 & & 0.98 & 1.05 & 0.98 \\
\hline Threonine & 0.12 & 0.15 & & & & & & & \\
\hline Serine & 0.25 & $0.14(0.17)$ & 0.14 & & & & & & \\
\hline Glutamic acid & 0.35 & $2.02(1.93)$ & 0.20 & & & $1.00(1.00)(1.03) \ddagger$ & 1.02 & 0.86 & 1.00 \\
\hline Glycine & 0.42 & $1.97(2.08)$ & 0.22 & 1.04 & & $1.02(1.02)(1.04)$ & & & \\
\hline Alanine & 0.19 & $0.97(1.05)$ & 0.14 & & & $0.95(0.98)(0.93)$ & & & \\
\hline Valine & 0.37 & $1.58(2.00)$ & 1.94 & & 0.99 & $1.41(1.73)(1.61)$ & 1.15 & 1.32 & 1.06 \\
\hline Leucine & 0.18 & $1.07(1.04)$ & 0.14 & 1.00 & & & & & \\
\hline$\mu$ moles $\S$ & 1.7 & 0.9 & 0.8 & 1.1 & 0.6 & 1.0 & & 0.4 & 0.8 \\
\hline Fragment of peptide\| & A-2 & A-3 & A-1 & B-5 & B-1 & B-3,4 + B-4 & & $\begin{array}{l}\text { B-2,3; } \\
\text { B-2 }\end{array}$ & B-2 \\
\hline Position in $\beta$-chain & 21 & $22-30$ & $18-20$ & $28-30$ & $18-19$ & (23) $24-27$ & & $20-23$ & $20-22$ \\
\hline
\end{tabular}

* $2.0 \mu$ moles hydrolyzed for $48 \mathrm{hr}$ in $0.25 \mathrm{~N}$ acetic acid $i n$ vacuo and in a boiling water bath; $1.6 \mu$ moles hydrolyzed for $24 \mathrm{hr}$ with Thermolysin $(2 \mathrm{mg})$ at $\mathrm{pH} 8.8$ and at $37^{\circ} \mathrm{C}$. Zones were obtained by column chromatography; the chromatogram of the thermolysin hydrolystate is depicted in Fig. 7. Data are from hydrolysates prepared with $6 \mathrm{~N} \mathrm{HCl}$ for $24 \mathrm{hr}$ at $110^{\circ} \mathrm{C}$ and in vacuo; data between parentheses are from analyses of $72 \mathrm{hr}$ hydrolysates.

† The same zone but isolated from a second Dowex 1:X2 chromatogram.

$\$$ Calculated on recovery of aspartic acid, or of glutamic acid or of arginine.

I| These fragments are explained in Fig. 6. 


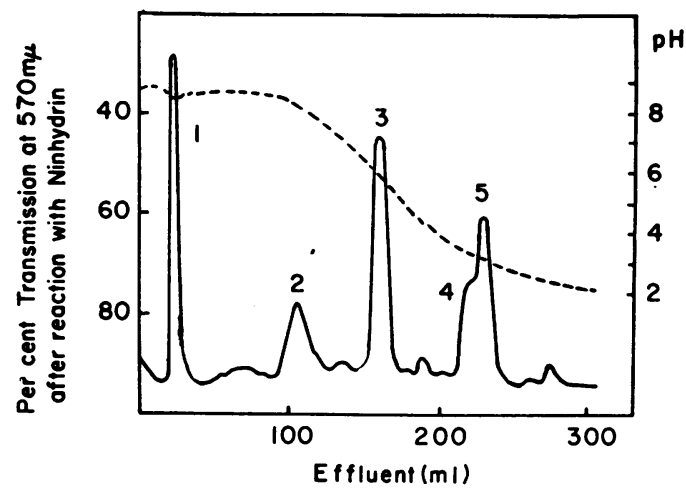

Figure 7 Elution profile of the thermolytic hydrolysate of the $\beta \mathrm{T}-3$ peptide of $\mathrm{Hb}-\mathrm{Savannah}$ on a $0.6 \times 60 \mathrm{~cm}$ column of Dowex 1-X2. The $\mathrm{pH}$ gradient is indicated by the broken line. For further details see Table IV and text.

positions 23,24 , and 25 is based on the following evidence. The low recovery of valine in $24 \mathrm{hr}$ hydrolysates of the $\beta T-3$ peptide and of appropriate segments of this peptide, and the increased recovery of this amino acid in long term acid hydrolysates is indicative for the presence of a Val-Val peptide bond. Analyses of segments resulting from hydrolysis of the $\beta T-3$ peptide with thermolysin readily excluded substitution of glycyl residue in position 29. The substitution of glycyl residue in position 25 is considered unlikely because the specificity of thermolysin, which is overwhelmingly directed towards bonds of the type X-Leu, X-Ile, X-Phe, and $\mathrm{X}-\mathrm{Val}$ (23), would otherwise have cleaved the Gly-Val bond resulting in the Val-Gly and Val-Glu-Ala peptides; these peptides were not observed in the Dowex-1 chromatogram. The data of the PTH degradation, although made on a mixture of two peptides, are consistent with a valyl residue replacing the glycyl residue in position 24.

Substitution of the glycyl residue in this position (or helical position B6) by an arginyl residue is observed in $\mathrm{Hb}$ Riverdale-Bronx ( $\mathrm{Hb} \mathrm{RB}$ ), a heat-unstable hemoglobin described recently by Ranney, Jacobs, Udem, and Zalusky (32). The abnormality in $\mathrm{Hb}$ Savannah concerns a second type of substitution of the glycyl residue which is considered to be one of the invariant residues, because the same amino acid residue is found in all normal myoglobins and hemoglobins (33). Glycyl residues $\beta-24$ (B6) and $\beta-64$ (E8) are in close spacial contact $(33,34)$, and substitution of the glycyl residue at $\beta-24$ by a valyl residue, as in $\mathrm{Hb}$ Savannah, or by an arginyl residue, as in $\mathrm{Hb} \mathrm{RB}$, will likely cause considerable conformational changes in the $\beta$-chain. The probable cause of the hemoglobin RB abnormality according to Ranney et al. is "a considerable distortion of the E-helix as well as the B-helix and thus of the relationships of the heme to the polypeptide chain, because the distal heme-linked histidine is the seventh residue of the E-helix and at least four additional heme contacts are present in this helix" (modified quote from reference 32). It seems conceivable that the glycine to valine substitution of the $\mathrm{Hb}$ Savannah abnormality would affect the stability of the hemoglobin molecule in a somewhat similar manner; apparently the close spacial contact between residues $\beta-24$ (B6) and $\beta$-64 (E8) also does not allow the introduction of a valyl residue at position $\beta-24$ without causing an instability of the molecule and an increased dissociation into dimers.

$\mathrm{Hb}$ Savannah could be separated from Hb A by starchgel electrophoresis at alkaline $\mathrm{pH}$, but chromatography on columns of DEAE-Sephadex failed to resolve the two components. Chromatography of red cell hemolysate of the Hb Savannah carrier on columns of Sephadex G-75 at $\mathrm{pH} 10.1$ resulted in the isolation of two additional fractions which are likely the $\alpha \beta^{\text {savannah }}$ dimer and free $\alpha$-chains, respectively (Fig. 3 and Tables I and II). Apparently the change in the tertiary structure of the $\mathrm{Hb}$ Savannah molecule also affects the $\alpha_{1}-\beta_{2}$ contact, causing an increased dissociation of the hemoglobin tetramer into dimers. This influence has to be indirect, because the sixth residue of the $B$ helix does not participate in the $\alpha_{1}-\beta_{2}$ contact (34).

As emphasized by Rieder et al. (6), treatment of $\mathrm{Hb} \mathrm{A}$ with $\mathrm{PMB}$ results in the attachment of the reagent to the $\beta-93$ cysteine residues followed by a dissociation of the tetrameric hemoglobin molecules into $\alpha \beta$ dimers. The SH groups in positions $\alpha-104$ and $\beta-112$ will become available to binding with $\mathrm{PMB}$ only under conditions of low $\mathrm{pH}$ and high ionic strength. Similar to $\mathrm{Hb}$ Philly (6), $\mathrm{Hb}$ Savannah dissociates readily into monomers under conditions of PMB treatment which are considerably milder than those required for the dissociation of normal hemoglobin A. It seems then that the glycyl to valyl substitution at position B 6 results not only in an increased dissociation of the tetramer into half molecules but also in a weakening of the $\alpha_{1}-\beta_{1}$ contact to the extent that an increased monomer formation occurs. This shift of the equilibrium between tetramer, dimer, and monomer towards the formation of monomers probably explains the presence of free normal $\alpha$-chains in red cells of the $\mathrm{Hb}$ Savannah carrier assuming that the free $\beta^{\text {Savannah }}$ chains will readily precipitate. The simple procedure used for the isolation of the $\beta^{\text {savannah }}$ chains which is based on the low solubility of the PMB $\beta^{\text {savannah }}$ chain in solutions of $\mathrm{pH} 6$ and moderately high ionic strength may well be applicable to other, unknown, unstable hemoglobin variants particularly when free $\alpha$-chains can be demonstrated in hemolysate of red cells from such carriers. 
Our data do not allow a reasonably accurate estimation of the relative amount of $\mathrm{Hb}-\mathrm{Savannah}$ in red cell hemolysate. According to the heat denaturation test approximately $30 \%$ of the hemoglobin is unstable (Fig. 2), whereas some $15 \%$ of the hemoglobin was eluted as the $\alpha \beta^{\text {savannah }}$ dimer from Sephadex G-75 columns (Fig. 3). The precipitate formed during the heat denaturation was not analyzed further. The possibility that mainly a mixed tetramer of the type $\alpha_{2} \beta^{\mathbf{A}} \beta^{\text {savannah }}$ precipitates under the condition of the experiment should be considered.

\section{ACKNOWLEDGMENTS}

We enjoyed the continuous cooperation of the family of the $\mathrm{Hb}$ Savannah carrier. We also would like to thank Dr. Walter A. Schroeder and Mrs. Joan B. Shelton for their help with the PTH degradation. Doctor Schroeder provided many helpful discussions.

This work was supported by U. S. Public Health Service Grants HE-05168, HE-12958, FR-5365, and HD-02800. Dr. Efremov was on leave from the Department of Biochemistry, Faculty of Agriculture, University of Skopje, Yugoslavia, and was supported by a grant under the Mutual Education and Cultural Exchange Act (The FulbrightHays Act) and by Medical College of Georgia Institutional Funds.

\section{REFERENCES}

1. Perutz, M. F., and H. Lehmann. 1968. Molecular pathology of human haemoglobin. Nature (London). 219: 902.

2. Lehmann, H., and R. W. Carrell. 1969. Variations in the structure of human haemoglobin, with particular reference to the unstable haemoglobins. Brit. Med. Bull. $25: 14$.

3. Huehns, E. R., and A. J. Bellingham. 1969. Annotation: diseases of function and stability of haemoglobin. Brit. J. Haematol. 17: 1 .

4. Carrell, R. W., and H. Lehmann. 1969. The unstable haemoglobin haemolytic anaemias. Seminars Hematol. 6: 116.

5. Rosemeyer, M. A., and E. R. Huehns. 1967. On the mechanism of the dissociation of haemoglobin. J. Mol. Biol. 25: 253 .

6. Rieder. R. F., F. A. Oski, and J. B. Clegg. 1969. Hemoglobin Philly ( $\beta^{35}$ tyrosine $\rightarrow$ phenylalanine) : studies in the molecular pathology of hemoglobin. J. Clin. Invest. 48: 1627.

7. Wintrobe, M. M. 1967. Clinical Hematology. Lea \& Febiger, Philadelphia. 6th edition.

8. Efremov, G. D., T. H. J. Huisman, L. L. Smith, J. B. Wilson, J. L. Kitchens, R. N. Wrightstone, and H. R. Adams. 1969. Hemoglobin Richmond, a human hemoglobin which forms asymmetric hybrids with other hemoglobins. J. Biol. Chem. 244: 6105.

9. Huisman, T. H. J. 1963. Normal and abnormal human hemoglobins. Advan. Clin. Chem. 6: 231.

10. Huisman, T. H. J., and A. M. Dozy. 1965. Studies on the heterogeneity of hemoglobin. IX. The use of tris(hydroxymethyl)aminomethane- $\mathrm{HCl}$ buffers in the anion-exchange chromatography of hemoglobins. J. Chromatogr. 19: 160 .
11. Dozy, A. M., E. F. Kleihauer, and T. H. J. Huisman. 1968. Studies on the heterogeneity of hemoglobin. XIII. Chromatography of various human and animal hemoglobin types on DEAE-Sephadex. J. Chromatogr. 32 : 723.

12. Andrews, P. 1964. Estimation of the molecular weights of proteins by Sephadex gel-filtration. Biochem. J. 91: 222.

13. Andrews, P. 1965. The gel-filtration behavior of proteins related to their molecular weights over a wide range. Biochem. J. 96: 595.

14. Betke, K., H. R. Marti, and I. Schlicht. 1959. Estimation of small percentages of foetal haemoglobin. Nature (London). 184: 1877.

15. Grimes, A. J., A. Meisler, and J. V. Dacie. 1964. Congenital Heinz-body anemia. Further evidence on the cause of Heinz-body production in red cells. Brit. J. Haematol. 10: 281 .

16. Anson, M. L., and A. E. Mirsky. 1930. Protein coagulation and its reversal. The preparation of insoluble globin, soluble globin and heme. J. Gen. Physiol. 13: 469.

17. Schroeder, W. A., R. T. Jones, J. Cormick, and K. McCalla. 1962. Chromatographic separation of peptides on ion exchange resins. Separation of peptides from enzymatic hydrolyzates of the $\alpha$. $\beta$, and $\gamma$ chains of human hemoglobins. Anal. Chem. 34: 1570.

18. Babin, D. R., W. A. Schroeder, J. R. Shelton, J. B. Shelton, and B. Robberson. 1966. The amino acid sequence of the $\gamma$ chain of bovine fetal hemoglobin. Biochemistry. 5: 1297.

19. Schroeder, W. A., and B. Robberson. 1965. An improved gradient for ion exchange chromatography of peptides on Dowex 1. Anal. Chem. 37: 1583.

20. Matsubara, H., R. Sasaki, A. Singer, and T. H. Jukes. 1966. Specific nature of hydrolysis of insulin and tobacco mosaic virus protein by thermolysin. Arch. Biochem. Biophys. 115: 324.

21. Ambler, R. P., and R. J. Meadway. 1968. The use of thermolysin in amino acid sequence determination. Biochem. J. 108: 893.

22. Benson, A. M., and K. T. Yasunobu. 1968. The action of the Bacillus subtilis neutral protease on S- $\beta$-aminoethylcysteinyl ferredoxin from Closstridium pasteurianum. Arch. Biochem. Biophys. 126: 653.

23. Bradshaw, R. A. 1969. The amino acid sequence of bovine carboxypeptidase A. III. Specificity of peptide-bond cleavage by thermolysin and the complete sequence of the cyanogen bromide fragment $F_{I I I}$. Biochemistry. 8: 3871.

24. Schroeder, W. A. 1967. Separation of peptides by chromatography on columns of Dowex 50 with volatile developers. In Methods in Enzymology. Vol. XI. C. H. Hirs, editor. Academic Press Inc., New York. 351.

25. Schroeder, W. A., J. R. Shelton, J. B. Shelton, J. Cormick, and R. T. Jones. 1963. The amino acid sequence of the $\gamma$ chain of human fetal hemoglobin. Biochemistry. 2: 992.

26. Hirs, C. H. W. 1956. The oxidation of ribonuclease with performic acid. J. Biol. Chem. 219: 611.

27. Jones, R. T., and G. Weiss. 1964. Long-path flow cells for automatic amino acid analysis. Anal. Biochem. 9: 377.

28. Baldridge, R. C., and H. B. Lewis. 1953. Diet and the ergothioneine content of blood. J. Biol. Chem. 202: 169.

29. Clegg, J. B., M. A. Naughton, and D. J. Weatherall. 1966. Abnormal human hemoglobins. Separation and 
characterization of the $\alpha$ and $\beta$ chains by chromatography, and the determination of two new variants, $\mathrm{Hb}$ Chesapeake and $\mathrm{Hb} \mathrm{J}$ (Bangkok). J. Mol. Biol. 19: 91.

30. Raftery, M. A., and R. D. Cole. 1966. On the aminoethylation of proteins. J. Biol. Chem. 241: 3457.

31. Schneider, R. G., S. Ueda, J. B. Alperin, B. Brimhall, and R. T. Jones. 1969. Hemoglobin Sabine beta 91 (F 7) Leu $\rightarrow$ Pro. An unstable variant causing severe anemia with inclusion bodies. N. Engl. J. Med. 280: 739.

32. Ranney, H. M., A. S. Jacobs, L. Udem, and R. Zalusky. 1968. Hemoglobin Riverdale-Bronx an unstable hemo- globin resulting from the substitution of arginine for glycine at helical residue B 6 of the $\beta$ polypeptide chain. Biochem. Biophys. Res. Commun. 33: 1004.

33. Perutz, M. F.. J. C. Kendrew, and H. C. Watson. 1965. Structure and function of haemoglobin. II. Some relations between polypeptide chain configuration and amino acid sequence. J. Mol. Biol. 13: 669.

34. Perutz, M. F., H. Muirhead, J. M. Cox, and L. C. G. Goaman. 1968. Three-dimensional fourier synthesis of horse oxyhaemoglobin at $2.8 \AA$ resolution: the atomic model. Nature (London). 219: 131. 